\title{
Comparison of Lichtenstein and total extraperitoneal laparoscopic hernia repair (TEP) methods in inguinal hernias
}

\section{Inguinal hernilerde Lichtenstein ve total ekstraperitoneal laparoskopik fitık onarımı (TEP) yöntemlerinin karşılaştırılması}

\author{
Serap Ulusoy ${ }^{1 *}$ (D) , Mehmet Özer ${ }^{1}$ (D), Özgür Albuz ${ }^{2}$ (D), Ömer Parlak ${ }^{3}$ \\ ${ }^{1}$ Ankara Atatürk Training and Research Hospital, Department of General Surgery, Ankara, Turkey \\ ${ }^{2}$ Keçiören Training and Research Hospital, Department of General Surgery, Ankara, Turkey \\ ${ }^{3}$ Yıldırım Beyazıt University, Department of General Surgery, Ankara, Turkey \\ * Corresponding author: Serap Ulusoy E-mail: serapulusoy13@gmail.com ORCID: 0000-0001-9014-7070 \\ Received: 26 September 2018 Accepted: 11 December 2018
}

\begin{abstract}
Aim: To compare Lichtenstein and TEP methods regarding the endocrine and inflammatory response to surgery and the results of early postoperative period.

Material and Method: 40 patients who had been operated for inguinal hernia at our clinic were included in the study. TEP was administered to the 20 patients while Lichtenstein was performed in another 20 patients. During the induction of anesthesia, postoperative 6th and 12th hours blood samples from the patients in both groups was obtained and serum ACTH, IL-6, WBC and CRP levels were measured. Results of early postoperative periods of operations were evaluated.

Results: There was no difference between the two groups in terms of surgical endocrine responses. Inflammatory response parameters varied. In patients TEP applied on WBC values and average checked at 6th hours at statistically significant degree higher while average of CRP values checked in 6th hours is lower at statistically significant degree in the patients with TEP than patients who underwent Lichtenstein operation. There were no significant differences detected in any period between Lichtenstein and TEP group in terms of IL-6 value. Postoperative VAS values of Lichtenstein group were statistically significantly higher than those of patients who underwent the TEP.

Conclusion: In study there wasn't difference between TEP and Lichtenstein repair in terms of inflammatory and endocrine responses. TEP repair, found to be superior than Lichtenstein repair operation; as it provides return to work early, the patients have less pain and less analgesic is needed, and less cost that promoted by the earlier return to work.
\end{abstract}

Keywords: inguinal hernia, Lichtenstein repair, TEP repair, hernia complication

() 2019 by the authors; licensee MEDITAGEM Ltd., Turkey. This article is an open access article distributed under the terms and conditions of the Creative Commons Attribution License (http://creativecommons.org/licenses/by/4.0/). 


\section{ÖZ}

Amaç: Bu çalışmada inguinal herni nedeni ile yapılan Lichtenstein ve TEP yöntemleri, cerrahiye endokrin ve inflamatuvar yanıt ve postoperatif erken dönem sonuçları açısından karşılaştırıldı.

Gereç ve Yöntem: Kliniğimizde inguinal herni tanısı ile opere edilen 40 hasta çalışmaya dâhil edildi. Hastaların 20'sine TEP, 20 'sine Lichtenstein onarımı yapıldı. Her iki gruptaki hastalardan anestezi indüksiyonu sırasında, postoperatif 6 . ve 12 . saatte kan alınarak serum ACTH, IL-6, WBC ve CRP düzeyleri bakıldı. Operasyonların postoperatif erken dönem sonuçları değerlendirildi.

Bulgular: Her iki grup arasında cerrahiye endokrin yanıt açısından fark bulunmadı. İnflamatuvar yanıtta parametreler değişkenlik göstermekte idi. TEP yapılan hastaların 6. saatte bakılan WBC değerleri ve ortalaması Lichtenstein yapılan hastalardan istatistiksel olarak anlamlı derecede daha yüksekken, yine 6. saatte bakılan CRP değerinin TEP yapılan hastalardaki ortalaması Lichtenstein yapılan hastaların ortalamasından istatistiksel olarak anlamlı derecede daha düşük bulundu. IL-6 değerleri açısından TEP yapılan grup ile Lichtenstein yapılan grup arasında hiçbir dönemde anlamlı farklılık saptanmadı. Lichtenstein yapılan grubun postoperatif VAS değerleri, TEP yapılan hastalardaki değerlerden istatistiksel olarak anlamlı derecede daha yüksek bulundu.

Sonuç: Çalışmamızda TEP fıtık onarımı ile Lichtenstein fıtık onarımı arasında inflamatuvar ve endokrin yanıt açısından anlamlı fark bulunmamıştır. TEP, hastaların erken işe dönmesi, daha az ağrı olması ve daha az analjeziğe ihtiyaç duyulması ve işe erken dönüşün de yarattığı daha az maliyet ile Lichtenstein fıtık onarımına göre daha üstün bulunmuştur.

Anahtar kelimeler: inguinal herni, Lichtenstein onarımı, TEP onarımı, herni komplikasyonları

\section{INTRODUCTION}

Inguinal hernia repairs are among the most common operations in the general surgery practice. Although there is no clear data for Turkey, approximately 800.000 patients are operated in USA every year. Various methods have been used for inguinal hernia operations throughout the history. These methods could be categorized in two groups; primary tissue approximation and tension-free repairs. Bassini, Mcway, Shouldice techniques are in the first group while Lichtenstein repair and laparoscopic repairs belong in the second. The first case about laparoscopic hernia repair was reported by Ralph Ger in 1982 [1]. In a case with right indirect inguinal hernia, neck of the hernia sac was closed with laparoscopy using a stapler and inserted into the right iliac fossa. Although this operation was done in November 1979, Ger implies that the first laparoscopic hernia sac repair was applied in West Indies University in Jamaica under the supervision of Dr. Fletcher. The real tension-free hernia repair with patch use in which the space is not sutured was introduced by Irving Lichtenstein et al in 1989 [2]. Lichtenstein repair is in the literature as the most commonly used hernia repair method.

In this study, we aimed to compare total extraperitoneal laparoscopic hernia repair (TEP) and Lichtenstein hernia repair methods.

\section{MATERIAL AND METHOD}

This study is a single-center and a prospective study. Approval of the ethics committee was taken on 11/27/2013 from the Ankara Yıldırım Beyazıt University Faculty Of Medicine Ethics Committee. Between December 2013 and February 2014, patients over 18 years old who had been operated for inguinal hernia at our clinic were included in the study. In this study patients who applied to our polyclinic and were diagnosed with inguinal hernia were separated into two groups of 20 patients randomly in respect to the time of admission one by one. The first group was applied TEP while the $2^{\text {nd }}$ had Lichtenstein hernia repair by the same team. Patients were compared according to their endocrine and inflammatory response to the surgery and postoperative early term results. Patients who had diabetes mellitus, immune system disorder of any kind, giant scrotal hernia and incarcerated hernia were excluded from this study.

Both groups were administered antibiotic prophylaxis before the operation. All of the patients who had TEP and 12 patients who had Lichtenstein hernia repair were applied general anesthesia. Remaining 8 Lichtenstein cases were applied spinal anesthesia. Prolene grafts of the same brand were used in both groups. Patients were mobilized in the postoperative early period and oral diet was administered. 
Patients whose preoperative preparations were made were taken into the operation by the same team. Patients' blood samples were taken during anesthesia induction and in the $6^{\text {th }}$ and $12^{\text {th }}$ postoperative hours and tested for adrenocorticotropic hormone $(\mathrm{ACTH})$, c-reaktive protein (CRP), white blood cell (WBC) and interleukin-6 (IL-6). A plain tube was used for IL- 6 while EDTA tubes for ACTH and WBC, a gel tube for CRP. ACTH, WBC and CRP were studied in the laboratory right away. Blood was centrifuged and serum was extracted for IL- 6 and kept in $-80{ }^{\circ} \mathrm{C}$. IL- 6 level was immunometrically measured with the DIAsource IL-6-EASIA Kit using the solid enzyme-tagged chemiluminescence technique. Plasma ACTH level was measured with the immulite-1 analyser using the chemiluminescence immunometric measurement techniques. CRP plasma level was measured with the Beckman Coulter Immage using the nephelometric method.

Patients were followed for 1 month in the postoperative period. They were called for a visit to the hospital at the end of 1 month and their control forms were filled by us. Their gender, age, preoperative complaint, smoking status, comorbidities were questioned. Preoperative and postoperative pain evaluation was made and visual analogue scale (VAS) was used with this purpose.

Review of systems, physical examination and bilateral inguinal region ultrasonography were applied during their visit. Cost analysis was done in coordination with billing department in our hospital.

As a result of our power analysis; In terms of early return to work and postoperative pain score; For these two variables that we reached, we found that the number of cases were sufficient. In terms of VAS; Both for type I Error $=0.05$ and in the $80 \%$ percent test power 0.80 ; The minimum number of subjects required for each group mean was found to be 12 in order to find a significant difference between the two groups.

On the other side, in calculation power analysis for return to the work time; The minimum number of subjects required for each group mean was found to be 15 in order to find a significant difference between the two groups.

In the statistical comparisons, Kolmogorov-Smirnow test was applied in order to determine the distribution of every variant groups and non-parametric statistical methods were applied to the variants which show normal distribution for the findings that do not show normal parametric distribution using SPSS-17.0 software. Student-t test (independent sample t test) was used as a parametric test
Table 1. Distribution of included patients

\begin{tabular}{|c|c|c|c|}
\hline & Lichtenstein & TEP & $\mathbf{P}$ \\
\hline \multicolumn{3}{|c|}{ Preop. Diagnosis } & \multirow{5}{*}{0.041} \\
\hline Right & $8(40)$ & $7(35)$ & \\
\hline Left & $9(45)$ & $4(20)$ & \\
\hline Bilateral & $2(10)$ & $9(45)$ & \\
\hline Relaps & $1(5)$ & $0(0)$ & \\
\hline Gender $M / F$ & $19 / 1(95 / 5)$ & $18 / 2(90 / 10)$ & 1.000 \\
\hline Smoking $\mathrm{Y} / \mathrm{N}$ & $6 / 14(30 / 70)$ & $9 / 11(45 / 55)$ & 0.327 \\
\hline \multicolumn{3}{|c|}{ Preop. Complaint } & \multirow{4}{*}{0.224} \\
\hline Swelling & $14(70)$ & $10(50)$ & \\
\hline Pain & $3(15)$ & $2(10)$ & \\
\hline Swelling and pain & $3(15)$ & $8(40)$ & \\
\hline Comorbidity $\mathrm{Y} / \mathrm{N}$ & $8 / 12(40 / 60)$ & $4 / 16(20 / 80)$ & 0.168 \\
\hline \multicolumn{3}{|c|}{ Operation } & \multirow{4}{*}{0.029} \\
\hline Right & $8(409$ & $7(35)$ & \\
\hline Left & $10(50)$ & $4(20)$ & \\
\hline Bilateral & $2(10)$ & $9(45)$ & \\
\hline $\begin{array}{c}\text { Anesthesia } \\
\text { General / Spinal }\end{array}$ & $12 / 8(60 / 40)$ & $20 / 0(100 / 0)$ & $<0.001$ \\
\hline
\end{tabular}

while Mann-Whitney $U$ test was preferred as nonparametric. Crosstab statistics were used in the comparison of categorical variants (chi square, Fisher's extract test). Mean and standard deviation was used in the summarizing of the numeric parameters while case volume (percentage) was used for the categorical variants. The limit for statistical significance was defined as (p) 0.05. Logistic and linear regression modeling were used to identify the impact of TEP and Lichtenstein operations on selected outcomes. Data were analyzed with SPSS for Windows 18 (SPSS-17.0, Chicago, IL).

\section{RESULTS}

Twenty patients were applied TEP and 20 other patients were treated with Lichtenstein repairs in our clinic. Patients' general distribution is shown in Table 1.

As is seen, there were no differences in preoperative complaints and findings of patients in both groups. Because of the TEP is the more indicated operation for bilateral inguinal hernias, it's percentage of bilateral inguinal hernia cases for the TEP operation the more than the Lichtenstein hernia repair group. In each group, patients were randomly selected according to their preference and indications according to their operation. In this selection; The for both TEP and Lichtenstein groups, after the operative risks and advantages factors explained to the all patients; operation type determined, according to patient desire. Of course, all patients Of course, all patients of TEP were administered general anesthesia while 8 patients of Lichtenstein group were applied spinal anesthesia. 
Table 2. Comparison of results of study groups

\begin{tabular}{|c|c|c|c|}
\hline & Lichtenstein & TEP & p \\
\hline WBC - preop. & $6345 \pm 2080.1$ & $6169.5 \pm 1644.45$ & 0.769 \\
\hline WBC 6th hour & $10995 \pm 3284.33$ & $13150 \pm 2760.73$ & $\mathbf{0 . 0 3 1}$ \\
\hline WBC 12th hour & $9998 \pm 2477.37$ & $11468,5 \pm 2238.51$ & 0.056 \\
\hline ACTH - preop. & $27.43 \pm 24.18$ & $40.4 \pm 52.23$ & 0.844 \\
\hline ACTH - 6th hour & $27.25 \pm 39.34$ & $58.2 \pm 66.78$ & 0.284 \\
\hline ACTH - 12th hour & $10.65 \pm 10.74$ & $10.05 \pm 8.39$ & 0.664 \\
\hline CRP preop. & $0.59 \pm 1.06$ & $0.28 \pm 0.28$ & 0.634 \\
\hline CRP - 6th hour & $0.84 \pm 1.09$ & $0.35 \pm 0.25$ & $\mathbf{0 . 0 1 1}$ \\
\hline CRP - 12th hour & $1.62 \pm 1.18$ & $1.2 \pm 0.59$ & 0.261 \\
\hline IL-6 - preop. & $848.14 \pm 1238.67$ & $363.63 \pm 680.39$ & 0.489 \\
\hline IL-6 - 6th hour & $379.84 \pm 398.77$ & $739.78 \pm 981.63$ & 0.912 \\
\hline IL-6 - 12th hour & $523.06 \pm 87.4$ & $373.67 \pm 505.04$ & 0.912 \\
\hline Age & $52.60 \pm 17.97$ & $51.00 \pm 17.96$ & 0.780 \\
\hline Preop. VAS & $2.85 \pm 1.63$ & $3.05 \pm 1.82$ & 0.857 \\
\hline Postop. VAS & $3.15 \pm 1.78$ & $1.20 \pm 0.77$ & $<\mathbf{0 . 0 0 1}$ \\
\hline Op. Duration & $38.25 \pm 16.48$ & $44.80 \pm 18.33$ & 0.242 \\
\hline Hospital stay & $1.25 \pm 0.79$ & $1.0 \pm 0.0$ & 0.152 \\
\hline Postop. Seroma Y/N & $2 / 18(10 / 90)$ & $0 / 20(0 / 100)$ & 0.487 \\
\hline Postop. Hematom Y/N & $1 / 19(5 / 95)$ & $0 / 20(0 / 100)$ & 1.000 \\
\hline Return to work time & $12.40 \pm 6.06$ & $7.25 \pm 2.40$ & $<\mathbf{0 . 0 0 1}$ \\
\hline
\end{tabular}

There were no differences in both groups regarding to endocrine response to the surgery $\left(p=0,284\right.$ on the $6^{\text {th }}$ hour, $\mathrm{p}=0.664$ on the $12^{\text {th }}$ ). Parameters show varieties in the inflammatory response. For example, WBC values and their average in the $6^{\text {th }}$ hour were significantly higher than open operations ( $p=0.031$ ) while CRP values of TEP patients in the $6^{\text {th }}$ hour were significantly lower $(p=0.011)$. There was no statistically significant difference between two groups in terms of other parameters ( $p>0.05$ ). Namely, no significant difference was found according to IL-6 values which we tested as an acute phase reactant between the groups which were applied TEP and Lichtenstein (Table 2).

There was no statistically significant difference between the groups according to VAS ( $p=0.857$ ) while the group which were operated open surgery had significantly higher postoperative VAS values than the values of patients in the TEP group $(p<0.001)$. Return to work times were statistically significantly shorter in the cases of TEP $(p<0.001)$ (Table 2 and 3). 2 patients developed seroma and hematoma who were applied Lichtenstein hernia repair when none of the TEP patients developed postoperative complications. However, this condition was not statistically significant.

No statistically significant difference was found between the groups from the point of duration of hospitalization and duration of operations.

Recurrences did not occur in any of the groups during follow-up.
Table 3. Outcomes*

*Logistic and linear regression performed; adjusting for differences in age, gender, smoking, comorbidity.

\begin{tabular}{|c|c|c|c|c|c|}
\hline $\begin{array}{c}\text { All Patients } \\
(\mathbf{n}: 40)\end{array}$ & $\begin{array}{c}\text { TEP } \\
(\mathbf{n}: \mathbf{2 0})\end{array}$ & $\begin{array}{c}\text { Lichtenstein } \\
(\mathbf{n}: \mathbf{2 0})\end{array}$ & $\mathbf{P} *$ & $\begin{array}{c}\text { Adjusted Odds } \\
\text { Ratio (95\%Cl)/ } \\
\text { Adjusted } \\
\text { Mean } \\
\text { Difference } \\
\mathbf{( 9 5 \% ~ C l )}\end{array}$ & $\mathbf{p}$ \\
\hline $\begin{array}{c}\text { Postoperative } \\
\text { VAS }\end{array}$ & $\begin{array}{c}\text { (95) } \\
0.20 \pm\end{array}$ & $3.15 \pm 1.78$ & $<0.001$ & $\begin{array}{c}\mathrm{AOR}(0.432),[(- \\
0.235),(0.038)]\end{array}$ & 0.008 \\
\hline $\begin{array}{c}\text { Return to work } \\
\text { time }\end{array}$ & $\begin{array}{c}7.25 \pm \\
2.40\end{array}$ & $12.40 \pm 6.06$ & $<0.001$ & $\begin{array}{c}\mathrm{AOR}(0.281), \\
{[(0.55),(0.003)]}\end{array}$ & 0.075 \\
\hline
\end{tabular}

\section{DISCUSSION}

One of the most common operations of general surgery teams is inguinal hernia repairs. Many methods have been developed with this purpose throughout the history. Laparoscopic methods have been used for the last 30 years and they replace open surgeries quickly in the world. However, there is no consensus in the method of hernia repair. When the literature is searched for hernia repair, it can be seen that the main problems are relapses, postoperative comfort, early return to work, costs etc. We also aimed to evaluate these topics in our study.

One hundred thirty patients were examined in a study conducted by Çelik et al. [3] in Istanbul in August 2012. Patients were applied TEP and followed for 3-60 months. 9 patients included in this study was relapsed. Average hospital stay was 1,2 days and active return to work was found 7 days, similar to our study. Scrotal fluid accumulation developed in 24 patients as the most common complication. Main artery and organ injury, surgical site infections were not found and TEP was considered to be among acceptable methods in this study.

In a study of Yoon Young Choi et al. [4] conducted in 2011 in Korea, 945 patients who were operated between 2002 and 2010 were evaluated. Sixty-six of them were incarcerated hernia cases while the rest were chronic inguinal hernia. In this study, TEP was implied to be a safe method which should be used in incarcerated and chronic inguinal hernia cases.

IS Jang et al. [5] applied TEP to two groups of primary and recurrent inguinal hernia and compared them according to operation duration and morbidity. As a result, no significant difference was found between two groups and TEP was stated to be a safe method in recurrent inguinal hernias.

In a study conducted by Meyer et al. [6] in the year 2013, 4565 patients were operated for TEP and a total of 27 complications were determined. It was emphasized that TEP 
is a safe and preferable method. It was found that complication rates reduce as the surgeon's experience increases.

In a meta analysis conducted by Zhu et al. [7] in 2013, a total of 12 publishes were examined which were made in between 1992-2013. Open extraperitoneal repair and TEP which were done for inguinal hernias were compared. There was no significant difference in terms of operation duration, recurrence, chronic pain, intraoperative complication, seroma, hematoma, surgical site infection and testicular problems while hospital stay was found to be shorter in TEP, return to normal activity was quicker and postoperative complications were found to occur less.

In a meta-analysis conducted by Karthikesalingam et al. [8] in 2010, studies published in between 1966 and 2009 were reviewed and TEP and open repair methods were compared in recurrent inguinal hernias. There was no difference in recurrence and chronic pain but postoperative pain was found to occur less in TEP. Similarly, there was no significant difference in development of hematoma. Surgical site infection occurred less in TEP. Return to work was significantly faster in TEP. It was emphasized that surgeon's preference is important in selection of surgical method in recurrent hernias.

Likewise, Kouhia et al. [9] compared Lichtenstein and TEP methods in treatment of recurrent inguinal hernias. It was found out that TEP is superior to Lichtenstein.

In a study of Singh published in 2008, laparoscopic and open repairs were compared in inguinal hernia cases. 60 patients were applied TEP while another 60 were applied Lichtenstein repair. Patients were followed for 3 years. Operation duration, hospital stay of TEP patients were found to be longer. Also, intraoperative and early postoperative complications, recurrences, pain and costs were found to be more than the ones in Lichtenstein hernia repair. There was no difference in long term results. As a result, it was suggested in this article that open repair should be preferred [10].

Although there are different results, in the above literatures; Especially in terms of early return to work and acute postoperative pain, as in the majority of literature; We have found that TEP's in hernia repair is especially advantageous in terms of these two features.

Also, the subject they all agree on is that TEP cases return to work quicker. Because of the fact that the majority of inguinal hernia patients are men who involve in work life, economic costs must be considered. Considering our study results showing that cost difference between two groups was only $300 \mathrm{TL}$, it is clear that the difference in early return to work in TEP covers for this cost.

As a result of linear regression, we found that postoperative pain decreased significantly with TEP as in univariate analyzes. In terms of early return the work, it was also significantly the better with TEP, but furthermore $p$ value was greater than $0.05(p=0.075)$. We think that our linear regression results are the more weak than univariate analyzes due to the number of limited cases. In conclusion, we can say that TEP method is more successful in terms of postoperative pain and early onset. In the next step, we want to do more with the number of cases with a multicenter and prospective study design.

\section{CONCLUSION}

Our study showed no significant difference between TEP and Lichtenstein hernia repair concerning inflammatory and endocrine responses.

Total extraperitoneal laparoscopic hernia repair was found to be superior in terms of early return to work, less pain and less requirement for drugs, along with the less cost created by possibility of early return to work.

\section{DECLARATION OF CONFLICT OF INTEREST}

The author declared no conflicts of interest with respect to the authorship and/or publication of this article.

\section{REFERENCES}

1. Ger R. The management of certain abdominal herniae by intra-abdominal closure of the neck of the sac. Ann Royal Coll Surg Engl 1982; 64: 342-4.

2. Lichtenstein IL, Shulman AG, Amid PK, Montllor MM. The tension-free hernioplasty. Am J Surg 1989; 157: 188-93.

3. Çelik A, Çelik AŞ, Ferlengez AG, et al. Total ekstraperitoneal preperitoneal (TEPP) yöntemle kasık fıtığı onarımı uygulanan hastalardaki sonuçlarımız. Med Bull Haseki 2012; 50: 119-21.

4. Choi YY, Kim Z, Hur KY. Laparoscopic total extraperitoneal repair for incarcerated inguinal hernia. J Korean Surg Soc 2011; 80: 426-30.

5. Jang IS, Lee SM, Kim JH, Kim BS, Choi SI. Clinical usefulness of laparoscopic total extraperitoneal hernia repair for recurrent inguinal hernia. J Korean Surg Soc 2011; 80: 313-8. 
6. Meyer A, Blanc P, Balique JG, et al. Laparoscopic totally extraperitoneal inguinal hernia repair. Twenty-seven serious complications after 4565 consecutive operations. Rev Col Bras Cir 2013; 40: 32-6.

7. Zhu $X$, Cao $H, M a ~ Y$, et al. Totally extraperitoneal laparoscopic hernioplasty versus open extraperitoneal approach for inguinal hernia repair: A meta-analysis of outcomes of our current knowledge. Surgeon 2014; 12: 94-105.

8. Karthikesalingam A, Marker SR, Holt PJ, Praseedom RK. Meta-analysis of randomized controlled trials comparing laparoscopic with open mesh repair of recurrent inguinal hernia. Br J Surg 2010; 97: 4-11.
9. Kouhia STH, Huttunene R, Silvasti SO, et al. Lichtenstein hernioplasty versus totally extraperitoneal laparoscopic hernioplasty in treatment of recurrent inguinal hernia a prospective randomized trial. Ann Surg 2009; 249: 3847.

10. The Internet Journal of Surgery. http://ispub.com/IJS/20/1/6908. Singh V, De U. Laparoscopic mesh versus open mesh repair of inguinal hernia. An experience from West Bengal, India. [cited: October /10/ 2018] 